\title{
Pages blanches
}

\section{Blanche Leblanc et Camille Noûs}

\section{OpenEdition \\ Journals}

Édition électronique

URL : http://journals.openedition.org/rdlc/7257

DOI : $10.4000 /$ rdlc.7257

ISSN : 1958-5772

Éditeur

ACEDLE

\section{Référence électronique}

Blanche Leblanc et Camille Noûs, «Pages blanches », Recherches en didactique des langues et des cultures [En ligne], 17-1 | 2020, mis en ligne le 06 avril 2020, consulté le 18 avril 2020. URL : http:// journals.openedition.org/rdlc/7257 ; DOl : https://doi.org/10.4000/rdlc.7257

Ce document a été généré automatiquement le 18 avril 2020

\section{(c) (1) $\odot$}

Recherches en didactique des langues et des cultures is licensed under a Creative Commons AttributionNonCommercial-NoDerivatives 4.0 International License 


\section{Pages blanches}

Blanche Leblanc et Camille Noûs

RÉSUMÉS

Article blanc

INDEX

Mots-clés : revues en lutte, université ouverte, sciences en danger, RDLC 